\title{
Simultaneous determination of purine derivatives in urine by high-performance liquid chromatography
}

\author{
M. Czauderna and J. Kowalczyk \\ The Kielanowski Institute of Animal Physiology and Nutrition, \\ Polish Academy of Sciences \\ 05-110 Jablonna, Poland
}

(Received 9 July 1996; accepted 13 September 1996)

\begin{abstract}
A high-performance liquid chromatography method for the analysis of allantoin, uric acid, hypoxanthine and xanthine in urine of sheep is described. Urine samples were analyzed directly after dilution. The combination of HPLC reversed phase $\mathrm{C}_{18}$ columns with monitoring the effluent at 205 $\mathrm{nm}$ provides a relatively rapid and simple analytical tool for studying purine derivatives in the urine of ruminants. Separation and quantification of purine derivatives was achieved using three $\mathrm{C}_{18}$ columns connected in a series together with a $\mathrm{NH}_{4} \mathrm{H}_{2} \mathrm{PO}_{4}-\mathrm{NH}_{4} \mathrm{H}_{2} \mathrm{PO}_{4}$ and methanol (95:5) gradicnt. The average recoveries of standard compounds added to urine samples were satisfaction (96-103\%). The low value of the intra-assay coefficient of variation and high recovery point to the satisfactory precision and accuracy of the reported method.
\end{abstract}

KEY WORDS: allantoin, uric acid, hypoxanthine, xanthine, urine, determination, HPLC

\section{INTRODUCTION}

The final products of nucleic acid purine base catabolism in most mammals are allantoin, uric acid, hypoxanthine and xanthine (Chen et al., 1990 a,b, 1993, 1996; Balcells et al., 1993; Susmel et al., 1994). These purine derivatives (PD) are

Financial support from CRS grant No. 5 S305 03307 is gratefully acknowledged 
excreted in urine, in which allantoin constitutes the greatest proportion (about $85 \%$ ) of total PD (Chen et al., 1993). The purine derivatives originate mainly from the nucleic acids of rumen microorganisms, so measurements of urinary PD levels provide an indication of the amount of microbial protein supplied to ruminants and is well correlated with organic matter or digestible organic matter intake (Antoniewicz et at., 1985; Lindberg et al., 1991; Balcells et al., 1993; Chen et al., 1993).

Although some authors have proposed allantoin excretion as an index of the microbial protein supply to the small intestine in ruminants, a more appropriate indicator might be the excretion of other or total purine derivatives (Topps et al., 1965; Zinn et al., 1986), particularly since ruminant urine also contains considerable amounts of uric acid, hypoxanthine and xanthine (Chen et al., 1990; Puchala et al., 1992). The main advantage of such an index is thatit does not require the use of an invasive method to estimate microbial biomass supply to the duodenum. Several methods have been developed for measuring PD (Fujihara et al., 1987; Chen et al.,1990b, 1996; Balcells et al., 1993; Puchala et al., 1993; Czauderna and Kowalczyk, 1995), but there are few reports that include simultaneous determination of allantoin, uric acid, hypoxanthine and xanthine (Balcells et al., 1992).

The aim of the present paper was to present a simple procedure for PD determination in urine without derivatization, using HPLC-UV detection. The application of such a method in the study of purine metabolism in ruminants might provide further evidence of the influence of nutritional manipulation on microbial protein supply to the small intestine.

\section{MATERIAL AND METHODS}

\section{Reagents}

Methanol was purchased from POCH (Gliwice, Poland), whilc allantoin, uric acid, hypoxanthine and xanthine were obtained from Sigma (St. Louis, MO, USA). All other chemicals were of analytical grade and purchased from POCH (Gliwice, Poland). Water was distilled and then deionized prior to use. HPLC-grade water was prepared using a Milli-Q system (Millipore, Toronto, Canada). The mobile phase (solvents A and B) was filtered through a $0.2 \mu \mathrm{m}$ membrane filter (Millipore). The solvents were degassed by $10 \mathrm{~min}$ ultrasonication prior to use. 


\section{HPLC configuration}

A Waters 625 LC system (including a controller and two pumps) was used. The apparatus consisted of a Waters 712 WISP autosampler, turnable Waters Model 486 absorbance detector and computer data handling system (all equipment from Waters, Millipore, MA, USA).

The analytical procedure, collection and data integration methods were developed using Millennium 2001 software and a Pentium 5P60 computer. Separations were achieved by using two Nova-Pak $\mathrm{C}_{18}-$ columns $(4 \mu \mathrm{m}$, $150 \mathrm{~mm}$ x $3.9 \mathrm{~mm}$ I.D., Waters, Millipore $)$ and a Chrompack column $-\mathrm{C}_{18}(4 \mu \mathrm{m}$, $100 \mathrm{~mm} \times 3 \mathrm{~mm}$ I.D., Chrompack, The Netherlands) connected in a series. A Waters cartridge ( $10 \mathrm{~mm} \times 6 \mathrm{~mm}$ I.D., Millipore, MA, USA) containing reversed phase $\mathrm{C}_{18}(30-40 \mu \mathrm{m})$ pellicular packing material was used as the precolumn.

\section{Analytical solvents and gradient composition}

A binary gradient program (Waters curvilinear program) was used for the complete analysis of allantoin, uric acid, hypoxanthine and xanthine in urine samples. The following eluents were used: $(\mathrm{A})-\mathrm{NH}_{4} \mathrm{H}_{2} \mathrm{PO}_{4}(0.0025 \mathrm{M})$ buffered to $\mathrm{pH} 3.5$ with $10 \%$ phosphoric acid; (B) - the solvent $\mathrm{A}$ and methanol $(95 / 5 \mathrm{v} / \mathrm{v})$. For the analysis of urinary purine metabolites, the solvent $B$ gradient was followed by the sequential steps: $0 \%$ the solvent $\mathrm{B}$ at $0 \mathrm{~min}, 80 \%$ at $21 \mathrm{~min}$ (linearly increased from $20 \mathrm{~min}$, line No. 6), $0 \%$ at $30 \mathrm{~min}$ (linearly decreased from $29 \mathrm{~min}$, line No. 6). The total flow-rate was $0.4 \mathrm{ml} / \mathrm{min}$ (the system pressure was $2200 \pm 50 \mathrm{psi}$ ). After $30.1 \mathrm{~min}$, the columns were re-equilibrated for $45 \mathrm{~min}$ in $100 \%$ solvent $\mathrm{A}$ at a flow-rate of $0.5 \mathrm{ml} / \mathrm{min}$ (the maximum system pressure was $2870 \pm 50 \mathrm{psi}$ ). Injection volumes were 5 or $10 \mu \mathrm{l}$. The detector was operating at $205 \mathrm{~nm}$ with an attenuation of 0.050 a.u.f.s (the absorbance unit full scale). The separation was performed at $17-27^{\circ} \mathrm{C}$.

\section{Standards}

Appropriate amounts of purine derivatives were dissolved in the solvent A. To provide calibration for urine samples, sets of purine derivative standards were used.

Urine was collected from sheep in metabolic cages and as a routine method of preservation, urine samples were acidified to a $\mathrm{pH}$ below 3 with $1 \mathrm{M} \mathrm{H}_{2} \mathrm{SO}_{4}$. For analysis urine samples were mixed and then diluted 1:40 or 1:20 with solvent $\mathrm{A}$. All standards and urine samples were filtered through a $0.2 \mu \mathrm{m}$ filter (Cole Parmers) into an autosampler vial and analyzed directly. 

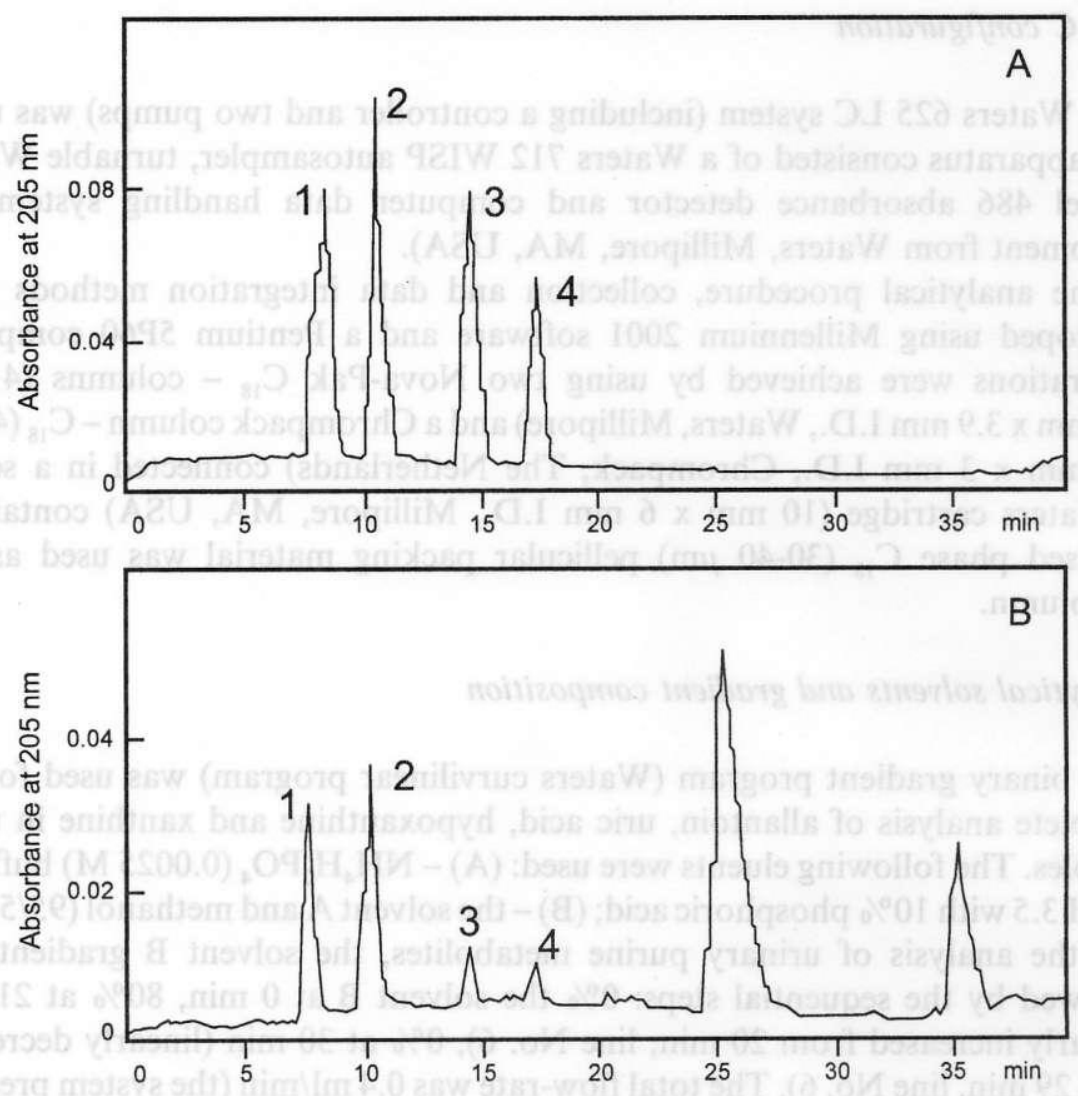

Figure 1. Chromatograms for standard (A) and urine (B). The peaks and their retention times are: (1) - allantoin at $8.2 \mathrm{~min},(2)$ - uric acid at $10.7 \mathrm{~min},(3)$ - hypoxanthine at $14.9 \mathrm{~min}$ and xanthine at $17.4 \mathrm{~min}$

\section{RESULTS AND DISCUSSION}

Good separation of all purine derivatives-allantoin, uric acid, hypoxanthine and xanthine in urine samples was achieved during the chromatographic run owing to the use the gradient program and monitoring the effluent at $205 \mathrm{~nm}$. Urine contains several components with a similar high polarity and UV absorption. Thus, a long column together with a low molarity and $\mathrm{pH}$ of the eluent were needed to achieve satisfactory separation of PD in urine samples, and to increase the theoretical plates so as to increase the retention time of the interfering species. In our procedure, the allantoin peak was eluted at $8.2 \pm 0.6$ min, uric acid at $10.7 \pm 0.8 \mathrm{~min}$, hypoxanthine at $14.9 \pm 0.9 \mathrm{~min}$ and xanthine at 
TABLE 1

Summarized results of recoveries $(\mathrm{R} \%$, i.e. mean $\pm \mathrm{SD}$ ) $\%$ of standard purine metabolites added to sheep urine and concentrations (C) of added purine derivatives, $\mu \mathrm{M}$

\begin{tabular}{|c|c|c|c|c|c|c|c|c|}
\hline \multirow[b]{2}{*}{ C } & \multicolumn{2}{|c|}{ Allantoin } & \multicolumn{2}{|l|}{ Uric acid } & \multicolumn{2}{|c|}{ Hypoxanthine } & \multicolumn{2}{|c|}{ Xanthine } \\
\hline & 187.2 & $(2)^{2}$ & 136.7 & (2) & 110.2 & (4) & 75.0 & (3) \\
\hline $\mathbf{R}$ & $102.2 \pm 3.8$ & & $104.1 \pm 4.6$ & & $98.2 \pm 1.4$ & & $102.2 \pm 2.8$ & \\
\hline C & 124.8 & (4) & 91.2 & (3) & 73.5 & (7) & 50.0 & (4) \\
\hline $\mathbf{R}$ & $101.3 \pm 3.4$ & & $97.7 \pm 3.8$ & & $99.4 \pm 1.1$ & & $101.9 \pm 1.9$ & \\
\hline $\mathrm{C}$ & 93.6 & (2) & 68.4 & (2) & 55.1 & (5) & 37.5 & (4) \\
\hline $\mathbf{R}$ & $98.7 \pm 4.1$ & & $99.2 \pm 3.3$ & & $100.5 \pm 0.9$ & & $95.1 \pm 4.6$ & \\
\hline C & 62.4 & (3) & 45.6 & (3) & 36.7 & (7) & 25.0 & (4) \\
\hline $\mathbf{R}$ & $96.8 \pm 4.7$ & & $103.8 \pm 4.3$ & & $100.7 \pm 1.8$ & & $102.6 \pm 3.5$ & \\
\hline $\mathrm{C}$ & 46.8 & (1) & 34.2 & (1) & 27.6 & (2) & 18.7 & (2) \\
\hline $\mathrm{R}$ & 96.2 & & 93.8 & & $103.4 \pm 6.5$ & & $96.1 \pm 5.4$ & \\
\hline C & 12.5 & (2) & 9.1 & (2) & 7.3 & (3) & 5.0 & (3) \\
\hline R & $98.3 \pm 5.3$ & & $95.3 \pm 4.4$ & & $103.8 \pm 3.7$ & & $97.1 \pm 6.1$ & \\
\hline Pooled data & $98.7 \pm 4.7$ & & $98.8 \pm 4.1$ & & $101.1 \pm 2.8$ & & $98.7 \pm 4.2$ & \\
\hline
\end{tabular}

' recovery was calculated as:

$$
R(\%)=\frac{\left(S_{1}-S_{0}\right) \times 100 \%}{S}
$$

where $S_{0}$ and $S_{1}$ are measurement before and after addition of standard purine derivatives, and $S$ is the amount of added purine derivatives

${ }^{2}$ number of replicates

$17.4 \pm 0.9 \mathrm{~min}$ (Figure 1). Good linearity was obtained for a wide range of PD standards concentrations and the following equations and correlation coefficients were calculated from the data:

- for allantoin (the range of concentration: $37.4-1496 \mu \mathrm{M}$ ):

$$
\mathrm{y}=2.992 \cdot 10^{-7} \cdot \mathrm{S}_{\mathrm{n}}+0.002, \quad \mathrm{R}=0.9999
$$

- for uric acid (the range of concentration: $27.3-1092 \mu \mathrm{M}$ ):

$$
\mathrm{y}=8.274 \cdot 10^{-8} \cdot \mathrm{S}_{\mathrm{n}}-0.010, \quad \mathrm{R}=0.9989
$$

- for hypoxanthine (the range of concentration: $22.0-880 \mu \mathrm{M}$ ):

$$
\mathrm{y}=5.565 \cdot 10^{-8} \cdot \mathrm{Sn}+0.005, \quad \mathrm{R}=0.9999
$$

- for xanthine (the range of concentration: $14.9-596 \mu \mathrm{M}$ ):

$$
\mathrm{y}=1.104 \cdot 10^{-7} \cdot \mathrm{S}_{\mathrm{n}}+0.001, \quad \mathrm{R}=0.9993
$$

where: $S_{n}$ and $y$ are the peak area and the purine concentration $(\mu \mathrm{M})$, respectively. 
TABLE 2

The within-assay coefficients of variations (C.V.) derived from the measurements of purine derivatives in urine samples

\begin{tabular}{ccccc}
\hline Allantoin & & Uric acid & Hypoxanthine & Xanthine \\
\hline $\mathrm{CV}^{1} \%$ 4.7 & $\cdots$ & 4.2 & 2.8 & 3.4 \\
$\mathrm{CV}^{2} \% 3.8$ & & 3.4 & 2.6 & 2.9 \\
\hline
\end{tabular}

' the within-assay C.V. based on thrce samples repeated three or two times (processing and injection)

2 the within-assay C.V. based on three samples each with three injection

The accuracy of the method was assessed by examining the recovery of known quantities of allantoin, uric acid, hypoxanthine and xanthine added to urine samples. Recoveries $(\mathbf{R})$ of standard purine metabolites added to the urine and the day-to-day precision of the method are presented in Table 1 . It can be scen that PD added to urine were recovered satisfactorily (96-103\%). The intra-assay coefficients of variation (CV) were calculated by repeatedly processing aliquots of spiked urine sample (Table 2) while the lowest concentrations of purine derivatives that gave a reproducible integration were: $9 \mu \mathrm{M}$ for allantoin, $2 \mu \mathrm{M}$ for uric acid, $1.5 \mu \mathrm{M}$ for hypoxanthine and $3.8 \mu \mathrm{M}$ for xanthine.

It can be concluded that the presented HPLC method for assaying purine derivatives makes it possible to scparate and quantify allantoin, uric acid, hypoxanthine and xanthine in urine samples. The urine samples can be analyzed directly after dilution. Moreover, the method described in this study enables simple and simultaneous determination of all PD without the disadvantages inherent in pre- or post-column derivatization procedures. The purine metabolites are detected at short wavelengths, as they possess a strong chromophore in the region 206-210 $\mathrm{nm}$ (Balcells et al., 1992; Chen et al., 1996). All purine derivatives were completely resolved in about $19 \mathrm{~min}$, however, the total run time, including column re-equilibration, was $75 \mathrm{~min}$.

\section{REFERENCES}

Antoniewicz. A., 1985. Urinary allantoin excretion and rumen microbial protein synthesis in sheep in relation to protein and energy intake. Rocz. Nauk. Zoot. 23, 169-181

Balcells J., Guada J.A., Peiro J.M., 1992. Simultaneous determination of allantoin and oxypurines in biological fluids by high-performance liquid chromatography. J. Chromatogr. 575, 153-157

Balcells J., Guada J.A., Castrillo C., Gasa J., 1993. Rumen digestion and urinary excretion of purine derivatives in response to urea suplementation of sodium-treated straw fed to sheep. Brit. J. Nutr. $69,721.732$ 
Chen X.B., Hovell F.D. DeB., Ørskov E. R., Brown D. S., 1990a. Excretion of purine derivatives by ruminants: effect of exogenous nucleic acid supply on purine derivative excretion by sheep. Brit. J. Nutr. 63, 131-142

Chen X.B., Mathieson J., Hovel F.D. DeB., Reeds P.J., 1990b. Measurement of purine derivatives in urine of ruminants using automated methods. J. Sci. Food Agric. 53, 23-33

Chen X.B., Kyle D.J., Ørskov E.R., 1993. Measurement of allantoin in urine and plasma by high-performance liquid chromatography with pre-column derivatization. J. Chromatogr. 617 , $241-247$

Chen X.B., Matuszewski W., Kowalczyk J., 1996. Determination of allantoin in biological, cosmetic, and pharmaceutical samples. J. Assoc. Off. Anal. Chem. Int. 79, 628-635

Crauderna M., Kowalczyk J., 1995. Determination of allantoin in blood by IPLC with pre-column derivatization. J. Anim. Feed Sci, 4, 351-358

Fujihara S., Ørskov E.R., Reeds P.J., Kyle D.J., 1987. The effect of protein infusion on urinary excretion of purine derivatives in ruminants nourished by intragastric nutrition. J. Agric. Sci., Camb. 109, 7.12

Lindberg J.E., 1991. Nitrogen and purine metabolism in preruminant and ruminant goat kids given increasing amounts of ribonucleic acids. Anim. Feed. Sci. Technol. 35, 213-226

Puchala R., Kulasek G.W., 1992. Estimation of microbial protein flow from the rumen of sheep using microbial nucleic acid urinary excretion of purine derivatives. Can. J. Anim. Sci. 72, 821-830

Puchala R., Shelford J.A.. Barej W., Kulasek G W., Piór H., Makoni N. Keyserlingk M.. 1993. Urinary excretion of pseudouridine and purine metabolites in ruminants. J. Anim. Physiol. Anim. Nutr. 69, 186-193

Susmel P., Spanghero M., Stefanon B., Mills C.R., Plazzotta E., 1994. Digestibility and allantoin excretion in cow fed diets differing in nitrogen content. Livest. Prod. Sci. 39, 97-99

Topps J.H., Elliott R.C., 1965. Relationship between concentration of ruminal nucleic acids and excretion of purine derivatives by sheep. Nature (London) 209, 498-499

Zinn R.A., Owens F.N., 1986. A rapid procedure for purine measurement and its use for estimating net ruminal protein synthesis. Can. J. Anim. Sci. 66, 157-166

\section{STRESZCZENIE}

\section{Jednoczesne oznaczanie pochodnych purynowych w moczu metodą HPLC}

Opisano metodę oznaczania allantoiny, kwasu moczowego, hipoksantyny i ksantyny w moczu owicc przy użyciu zestawu HPLC. Mocz analizowano bezpośrednio po doprowadzeniu do pH 3 oraz odpowiednim rozcieńczeniu. Pochodne purynowe rozdzielono wykorzystując trzy kolumny $z$ odwróconą fazą $\left(C_{18}\right)$ poprzez elucję gradientową i monilorowanie przy $205 \mathrm{~nm}$. Zmiany w składzie fazy ruchomej $(0,4 \mathrm{~m} / /$ nin) realizowano programowo przez zmiany względnej prędkości podawania dwóch roztworów - A $\left(0,025 \mathrm{M} \mathrm{NH}_{4} \mathrm{H}_{2} \mathrm{PO}_{4}\right)$ i B - (roztwór A i metanol: $95 / 5 \mathrm{v} / \mathrm{v}$ ). Odzysk pochodnych purynowych dodanych do moczu był niemal zupełny. Mała wartość współczynnika zmienności w obrẹbie próby (przygotowanie i iniekcja) oraz iniekcji tej samej próby, wysoki odzysk oznaczanych związków (96-103\%) dowodzi, że prezentowana prosta metoda jest dostatecznie doktadna. 